stated whether the gift be for the ambulance, the Danube hospitals, or the Princess Elizaheth's cottage bospitals. In these latter I dare hope that the sick and suffering of every nation and of every creed will alike meet with sympathy and succour. The local press is making an appeal on behalf of the sufferers from the bombardment of Giurgevo. Women, children, and old people are homeless and bread. less, their cottages heaps of ruins, and they sleep in the vines. Some have reached here in a heart-rendering condition, and are relieved by private charity.

Apologising for trespassing so much on your valuable space, I have the honour to be, Sir,

60, Strada, Coltzi, Bucharest,

Yours faithfully,

Sept. 10th, 1877

E. B. MAWER.

\section{A GOOD EXAMPLE}

To the Editor of THE LANCET.

SIr,-Lately, I was requested by the staff of the Epsom and Ewell Cottage Hospital to visit one of the patients in that institution at Epsom. I did so. A few days subsequently I received a note from the committee containing a cheque for five guineas as an acknowledgment of my service, but expressing regret at the smallness of the amount offered, their funds being low.

The above was a simple act of justice, but amounts to generosity when contrasted with the niggardly conduct of the managers of medical charities, both large and small. Many of these, not satisfied with the time and labour willingly expended by the staff upon the patients, exact a further direct outlay of both time and money for repeated journeys to and from the hospital. This is unjust. Yours, \&c.,

Queen Anne-street, W., Sept. 14th, 1877.

$$
\text { C. F. Maunder. }
$$

\section{GLASGOW}

(From our own Correspondent.)

A FEW months ago some hospital irregularities were made the subject of considerable comment by one of our daily papers, owned and edited by Dr. Charles Cameron, M.P. It was at one time thought that attention having been directed to the subject no further notice would have been taken of it by the Crown authorities, to whom the matter had been referred, and considerable surprise was created by the apprehension last week of the medical superintendent, the reaident assistant, matron, and nurse of the hospital in question. It would be injudicious to enter into further details at present, as all facts connected with the case will soon be laid bare, shorn of the sensationalism necessary to foster and attract the curiosity of the general public. Meanwhile a subscription has been begun, and we understand has been liberally responded to among the profession in Glasgow, towards defraying the necessary outlay incumbent on obtaining a proper defence of the resident assistant, who is chiefly inculpated. It is to be noted, as indicating the tone of professional opinion, that the name of the senior M.P. does not head this list, and it may be legitimately assumed that he will not be asked to subscribe. None of our other papers took any notice of the affair until the steps taken by the Procurator Fiscal compelled them to break a very meritorious silence.

Professor George H. B. McLeod's appointment as surgeon to the Queen in Scotland has given universal satisfaction to the profession bere. It was understood that his former opponent for the Surgery chair was also emulous of obtaining Royal favour, and for a time considerable doubt was entertained as to which of the two would be successful. His disappointment may be tempered by the fact that our city and century show on this and on other occasions that "there is something in a name," if its owner is worthy of subsequent promotion.

It is to be hoped that the Government will soon fill up the vacant chair of Anatomy at the University. The vacancy has not excited half the professional interest occasioned by the retirement of the Professor of Physiology last summer.
Indeed, it would seem as if the Medical Faculty in the Senatus were unaware of Professor Allen Thomson's resignation, fur they still loyally head their wekly contribation to your advertising columns with his distinguished name. This vacancy is a peculiar one in university annals, as it is generally understood that Glasgow has only sent forth one candidate for the appointment, and Edinburgh has not even entered the field.

In a recent trial at the Circuit Court, with regard to the effect of putrid pork on man's constitution, some dis. crepancy of medical opinion was elicited, and the situation reached a climax when the judge, with the assent of the adrocate-deputy, quashed the case without appealing to the jury, and threw himself with charming candour into the arms of the Edinburgh expert. Our local men complain, and not unjustly, that they were ill-used.

The annual Faculty elections take place in the beginning of next month. It is assumed that the new president will, as in former years, be appointed unanimously, although at one time there was a whisper of a contested election. The other vacancies in the examining body may occasion a little breeze, but even this is doubtful.

Dr. Foulis's case, to which you alluded last week, is progressing eatisfactorily. The details of the operation and subsequent treatment will be looked forward to with interest, as it is understood that it is the first time in this country that excision of the larynx has been performed.

Glasgow, September 17th, 1877.

\section{VICHY.}

\section{(By our Roaming Correspondent.)}

As a continuation of the series of letters written last autumn, in which some five or six baths and health resorts were brought in review before the readers of THE $L_{A N C E T}$, I purpose to try to bring as graphically as may be under the eje of the reader that famous French bathing-place the name of which heads this letter.

He who knows Vichy only by referring to the map of France might be led to think, from the small type ac. corded to the name of the town, that it is a place of very inconsiderable size. This is not the case. It is a large flourishing place; and the appearance of the railway station, with its enormous waiting-room and its long line of carriages and hotel-omnibuses, is sufficient to dispel at once any preconceived notions as to inferiority of size which the traveller may have entertained. Vichy is at the extreme south of the department of Allier, and stands on the right bank of the river, a tributary of the Loire, which gives its name to the department. It is surrounded by hills of moderate elevation, except towards the south, where it is bounded by the river Allier and the rich alluvial plains be. yond it. The soil is $\mathrm{dry}$ and porous. It is to a great extent protected from cold winds by the hills, and, being nearly six degrees of latitude south of London, it would be considered by the English as a warm climate, although the French, whose territory is washed by the Mediterranean, speak of it as temperate. The difference in climate is well shown by a glance at the market, where melons are sold more as vegetables than as fruits, and ruddy peaches piled in big baskets gladden the ejes of gourmets. The town is very well built, and was immensely improved ander the imperial rule of Napoleon III. The most important work, perhaps, was the reclamation of the shore of the Allier, and the embankment of the river on the side of the town. By this work, what was once an uninteresting and unhealthy waste of stone and sand, generally dry, and only covered by the river in times of flood, has become a splendid park, with pleasant walks, gay flower-beds, and a great variety of trees, which afford a grateful shelter to those who seek their recreation here. Besides this river-side park, which is nearly three-quarters of a mile in length and about a hundred yards in width, there is another park in the centre of the town, which is well laid out and planted, and which is bordered on either side by ranges of hotels, and at either end by the "Etablissement des bains" and the Casino. The hotels are all that can be desired-well built, spacious, clean, and provided with most modern sanitary requirements; and the 